\title{
Clinical and immunological presentation of new HIV-infected patients in an outpatient clinic
}

\author{
Edna Quintas, Sara Cardoso, Carmela Pineiro, Danina Ferreira, Rosario Serrao, Jorge Soares, Rui Marques*, \\ Antonio Sarmento
}

From $16^{\text {th }}$ International Symposium on HIV and Emerging Infectious Diseases

Marseille, France. 24-26 March 2010

\section{Background}

Current guidelines of antiretroviral therapy (ART) recommend starting ART before an advanced immunological deterioration. The benefit of early ART is lost when diagnosis is established at an advanced stage of the disease. The aim of this study is to evaluate the clinical and immunological data at the first observation of HIV-infected patients in an Infectious Diseases Service.

\section{Methods}

Demographic and epidemiological data of all HIVinfected patients diagnosed between 01/January/2006 and 31/December/2008 were evaluated. Clinical and immunological status, AIDS defining entities and mortality rate were also analysed.

\section{Results}

311 new patients were observed (305 HIV-1 infected and 6 HIV-2 infected), with a mean age of $42 \pm 13,7$ years. $218(70 \%)$ patients were men. Risk factor for HIV-infection was sexual in $271(87 \%)$ patients $(18 \%$ were homo-bisexual). At the time of diagnosis the mean CD4+ cell count was $333 \pm 305$ cells/mm3; $132(42,4 \%)$ patients had CD4 cell count $<200 / \mathrm{mm}^{3}$. In $89(28,6 \%)$ patients an AIDS-defining illness was diagnosed simultaneously with HIV-infection diagnosis; $43 \%$ of these were tuberculosis. After a mean follow-up of $15 \pm 9,7$ months $27(8,6 \%)$ patients died, 24/27 (88,8\%) with AIDS and the other 3 patients one each with eosophageal cancer, hepatic failure and MSSA sepsis,. In 22/27 (81,4\%) of the deceased patients the CD4 cell count was $<200$ cells $/ \mathrm{mm}^{3}$ at the time of the HIV diagnosis.

* Correspondence: rmarques@hsjoao.min-saude.pt

Infectious Diseases. Hospital Sao Joao, Porto, Portugal

\section{Discussion}

In the last 3 years, $42 \%$ of the new diagnosed patients had a serious immunological deficit. In $28 \%$ of them HIV-infection was diagnosed simultaneously with a defining AIDS opportunistic infection. The fact that $81,4 \%$ of the deceased patients had a CD4 cell count $<200 / \mathrm{mm}^{3}$ at diagnosis shows that HIV-infection diagnosis was done too late for ART to be of benefit.

Published: 11 May 2010

doi:10.1186/1742-4690-7-S1-P39

Cite this article as: Quintas et al:: Clinical and immunological presentation of new HIV-infected patients in an outpatient clinic. Retrovirology 2010 7(Suppl 1):P39.
Submit your next manuscript to BioMed Central and take full advantage of:

- Convenient online submission

- Thorough peer review

- No space constraints or color figure charges

- Immediate publication on acceptance

- Inclusion in PubMed, CAS, Scopus and Google Scholar

- Research which is freely available for redistribution

Submit your manuscript at www.biomedcentral.com/submit
C Biomed Central 